\title{
Literature review of Strategy Based Instruction (SBI) development in Teaching English as Second Language(TESOL)
}

\author{
Yunlin $\mathrm{Shi}^{1,2}$ \\ ${ }^{1}$ Hubei University of Technology and Engineering College, Wuhan, China \\ ${ }^{2}$ Florida Atlantic University, Boca Raton, Florida, United States
}

Keywords: SBI, TESOL, literature review.

\begin{abstract}
This paper is a literature review of Strategy-based instruction in Teaching English as Second Language (TESOl) around the world. With the globalization and modernization, English plays increasing role in exchange and communication, then how to improve the teaching efficiency in TESOL becomes more important. SBI combines the real teaching and learning strategy instruction esp.the examples and specific purposed practice. Many teachers around the world have been employing this strategy in real teaching practice, some got significant result in comparison, some think it potentially helpful although no obvious except only minor empirical database analysis advantage.
\end{abstract}

\section{Introduction}

Language learning strategies(LLS) has been receiving ever-growing attention in foreign language teaching and learning (Oxford 1990, Cohen 1990, O'Malley\&Chamot 1990, Wenden 1991, Brown 1991, Rubin\& Thompson 1994, Mendelsohn 1994, McDonough 1995, Cohen 1996, Anna uhl Chamot 2005, 2007, Yunlin Shi 2008.) Appliedlinguists have been exploring language learner strategies for more than 30 years (Gu, Y 2007, Dingfang Shu 2011, Qingquan Ni 2014), much of this history has been sporadic. The 1980s and early 1990s were a period of substantial research on learning strategies in the west. Recently, a number of new investigations have reinvigorated the field (Anna UhL Chamot, 2005).

\section{Learning strategy}

Though there are so many theoretical and empirical studies on all the factors affecting learning strategy use. Practically, variables function together as a system (Wen\&Johnson, 1997).

Table 1 Conceptual model of factors affecting English achievement

(Wen\&Johnson, 1997)

\begin{tabular}{|c|c|c|c|c|}
\hline \multicolumn{2}{|c|}{ Non-learner factors } & \multicolumn{2}{|c|}{ Learner factors } & \multirow[t]{2}{*}{ Outcomes } \\
\hline Environmental & Institutional & Unmodifiable & Modifiable & \\
\hline Social & School resources & Intelligence & Learning purposes & \\
\hline Economic & Teaching qualities & Aptitude & Beliefs & \\
\hline Cultural & Assessment & Sex & Effort & \\
\hline Linguistic & methods & Age & Management strategies & \\
\hline Contexts & & Prior learning & Language learning & \\
\hline Family & & & strategies & \\
\hline background & & & & \\
\hline Presage $^{-}$ & 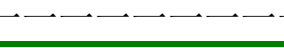 & $\rightarrow$ proce & product & $\rightarrow$ \\
\hline
\end{tabular}

The model in table 1tells that although both non-learner and learner factors affects outcomes, Modifiable factors is the key part to affect the outcomes, through which the non-learner factors to influence the outcomes, and also through which unmodifiable learner variables to do so either directly or indirectly, and among which, all will be operated well through language learning strategies (see Wen\&Johnson, 1997). So learning strategy is truly significant for English learners when analyzing the factors that affecting the outcome. 
Within the field of ESL, there is considerable debate on defining learning strategies. No strong consensus has been reached yet (Ellis, 1994). As Rubin (1987) described, learning strategies are strategies that contribute to the development of the language system that construct and affect learning directly. As Oxford (1990:18-22) defined, learning strategies as "specific actions, behaviors, steps, or techniques that students (often intentionally) use to improve their process in developing L2 skills. Strategies can facilitate the internalization, storage, retrieval, or use of the new language. Strategies are tools for the self-directed involvement necessary for developing communicative ability"

Oxford (1990) has a strategy classification system which is more comprehensive and detailed, more systematic in four language skills (listening, reading, speaking, and writing).It divided learning strategies into two main categories: direct and indirect strategies. Direct strategies deal with the new language and work with the language itself in a variety of specific tasks and situations. Direct contains: memory, cognitive, compensation; indirect contains: metacognitive, social, and affective. Memory is keeping a recalling new input; cognitive is understanding a new language; compensation is using linguistic or contextual clues; metacognitive is planning, managing, monitoring or evaluating one's own leanring; social is interacting with others; affective is controlling and developing one's emotion.

\section{Strategy Based Instruction (SBI)}

Strategies themselves are not inherently good or bad, but have the potential to be used effectively (Cohen, 1998, P.8) Since learning strategies are playing so promising role in English learning, then many found proved that more able students are higher in frequency in using more strategies. (Yunlin Shi, 2008; Thitipat Watthjarukiat, 2012, Rana Yildirim, 2015)

As a form of learner-focused language teaching, SBI explicitly combines strategy training activities with everyday classroom language instruction (see Oxford, 2001; Cohen \& Dörnyei, 2002). SBI emphasizes both explicit and implicit integration of language learning and use strategies in the language classroom and the key underlying premise of SBI is that the learners should be given the opportunity to understand not only what they can learn in the language classroom, but also how they can learn the language they are studying more effectively and efficiently (Cohen, 2007). After SBI assisting, the learners should have sharper sense of strategy: what the concrete strategies are and how to organize and use systematically and effectively. Gu. Y (2007) said that a strategy suitable for one particular person, task, or learning context may not be suitable for another, SBI is more or less person-related, task-related, or learning context related, so SBI will be definitely beneficial to every learner.

SBI steps are usually five. These are: 1) Awareness-raising and preparation, 2) Teacher presentation and modeling, 3) Multiple practice opportunities, 4) Evaluation of strategy effectiveness, and 5) Transfer strategy to new tasks (Chamot, Barnhardt, El-Dinary, and Robbins 1999). In a word, five steps: preparation, presentation, practice, evaluation and expansion (Chamot, 1999). It is a circle. From the preparation stage to the expansion stage, responsibility of strategy use details is gradually shifted from teachers to learners. Students that they think more effective, apply those strategies to new classes, and update their own individual combinations and interpretations of learning strategies. By this stage, the target of SBI has been achieved, because students have become independently strategic and they are able to reflect on and regulate their own learning. Ongoing monitoring of learners' use of both individually and instructed developed strategies is critical if teachers are to scaffold their guides and instructions successfully. In SBI, teachers begin with explicit instruction and then gradually reduce prompts and cues to students. Gradually, students begin to assume responsibility for the self learning regulation.

A SBI tutor is more than a teacher. The teacher should be a wonderful diagnostician to help the students to find their real English level and weak points in language learning strategies; an excellent negotiator to train the learners to grasp the related strategies, to coach them how to apply the strategies to the specific content; as a language learner also, who is always having great passion in learning language. (Cohen, 2000:99) 
SBI model is practiced by many researchers in real teaching around the world. Cohen(1996) connected SBI with speaking and found SBI is in favor of foreign-language classroom(p28). And in this way, the students get accustomed to content-centered plus strategy-centered teaching. And Cohen (1996) pointed out that there is more need to conduct further empirical study on SBI. Then some scholars did research in this field further.

Gu, Y (2007) presented a strategy intervention study in Singapore involving 246 grade 5 primary school students over a whole semester and conclude that SBI is an empowering tool for learners and teacher development. Peter confirmed that the question was no longer whether SBI should be promoted, it was a matter of how. Three prerequisite is stressed: 1 , complete understanding and cooperation from the schools; 2 , the full support and cooperation from teachers involved; 3 , the close collaboration between researchers, teachers and the school management. Any weak point in these three prerequisite accomplishments in practical teaching will lead to discount in efficiency. Gu, Y focused the SBI on general English study. It is comprehensive, while some other scholars did research in specific fields.

For instances, Elham, Ali(2014) experimented a practical SBI on L2 learners' persuasive writing. It is found that SBI allows 60 Irannian EFL undergraduates to attain a positive sense of self-efficacy and "this is essential to foster critical thinking skills"(p235). And also inspiration are given to us that to the present researchers, seldom have been conducted with English as a foreign language(EFL) undergraduate university students.

Besides, Chou(2015) Morley(2001) emphasized listening is essential. A study by Watthajarukiat (2012) focused on listening comprehension strategies used by undergraduate students, and found frequencies of strategy use in more able students were higher than that in the less able ones. Graham, Santos and Vanderpank(2011) suggests that learners understand what they hear well if they are aware of the effective ways of using strategies to deal with various tasks, metacognitive work with cognitive can lead to listening improvement. But these researches are just descriptive, not intervening or empirical.

Only Carrier (2003) carried a strategy instruction on ESL students' listening comprehension, the result showed that it has positive collection.He took a closed-book examination, and studied strategies that could increase deep processing correlated positively with scores, but SBI were not likely to be used by all the 46 students. And he provided a new aspect to observe, from an open-book, open-note examination, strategies that possibly have led to confusion considering the locations of material in the textbook and lecture notes related negatively with scores.

But Wilson (2003), critic of SBI listening, who introduced a new approach in teaching L2 listening based on the notion of bottom-up primacy, a learner-centered, task-based teaching, named it Discovery Listening. Amir Marzban(2012) compare the effect of explicit SBI and Discovery Listening(DisL) on the Iranian EFL Listening comprehension, and found that no significant difference between SBI and DisL methods, but DisL is more enjoyable in teaching process than SBI model to the students. Amir (2012) found SBI is less enjoyable. Dornyei (2005) said that strategies should be abandoned.

In China, strategy research is ten years later than the west (2008, Yunlin Shi, HuajiaWu, 2009, Yurong Zhen, 2011), it is still the hot topic (Dingfang, Shu, 2013, Bing Wang, 2013).A comprehensive review of learner strategy studies by many researchers (Qiufang, Wen2004, Qingquan, Ni, 2008, Yurong Zheng, 2011). They concluded that most of the paper are descriptive, very seldom is empirical. In China, evidence of strategy training effectiveness can be found for oral English (Xiaofang, Gao, 2004), reading comprehension(Hong, Liu, 2011). But the scholars in China only are limited on discussing whether SBI could be combined with writing and reading teaching, at present, no expectation is taken into practice in real teaching. So combining the strategy and the teaching practice will be the future research trend.

\section{Conclusion and inspiration}

As this review has demonstrated, there is lots of interesting work going on in SBI, for instance, the future empirical research objects should cover adult, middle school students, or university Arts 
students etc; the research scope should be widened from writing, reading to speaking and listening or even grammar; the monitoring process should be expanded from one semester to keeping track of several years; more scientific statistics methods should be employed in linguistics research, until now, most linguistics scholars are only basic SPSS users, they'd better cooperate with other statistics specialists; SLA study should not be confined to TESOL but an area which needs cooperation with other fields, for example, psychologists, biologist, philologist, mathematician etc; the research should better be followed by close cooperation between a group or a team inside which there are western and Chinese scholars from different areas who exchange mutual ideas so frequently and effectively that bring about more innovative inspirations or findings grounded in solid research, from both quantitative and qualitative paradigms. These studies will hopefully take SBI research to a new level of maturity.

\section{References}

[1] Amir Marzban.(2012).Discovery Listening and Explicit Strategy-Based-Instruction Models' Effect on the Iranian Intermediate EFL Listening Comprehension.Procedia-Social and Behavioral Sciences.Volume 46.P5435-5439.

[2] Andrew D. Cohen. (1996). The impact of strategies-based instruction on speaking a foreign language. Research Report. University of Minnesota.

[3] Anna Uhl Chamot (2005). Language learning strategy instruction: current issues and research. Annual Review of Applied Linguistics, 25, pp 112-130.

[4] Bing Wang.(2013). The research on the relationship between English learning process and the outcome in China. Northeast Normal University. Changchun, China.

[5] Brown, H.D. (1991). Breaking the language barrier. Yarmouth, ME: Intercultural Press.

[6] Chamot, A.U., Barnhardt, S., El-Dinary, P.B., \& Robbins, J. (1999). The learning strategies handbook. White Plains, NY:Addison Wesley Longman.

[7] Chou, Mu-hsuan.(2015)Impacts of the Test of English Listening Comprehension on Student's English Learning Expectations in Taiwan. Language, Culture and Curriculum.Volume 28, Issue2, 2015 .P191-208.

[8] Cohen, A. D. (1990). Language Learning: Insights for learners, instructors, and researchers.

NY: Newbury House/Harper Collins.

[9] Cohen, A. D. (1998). Strategies in learning and using a second language. London: Longman.P.8

[10] Cohen, A. D.(2000). Strategies in Learning and Using a Second Language. Beijing: Foreign Language Teaching and Research Press. p99.

[11] Cohen, A. D., \& Dörnyei, Z. (2002). Focus on the language learner: Motivation, styles, and strategies. In N. Schmitt (Ed.), An introduction to applied linguistics : 170-190. London: Arnold.

[12] Cohen, A. D., \& Macaro, E. (Eds.).(2007). Language learner strategies: 30 years of research and practice. Oxford: Oxford University Press.

[13] Dingfang Shu.(2013).The Plan and Arrangement about Foreign Language Teaching in China [J]. Foreign Language Teaching and Research (5):432. Beijing, China.

[14] Dornyei, Z.(2005). Language learning strategies and student self-regulation. In The psychology of the language learner: Individual differences in second language acquisition(pp.162-196).Mahwah, New Jersey: Lawrence Erlbaum Associates, Publishers. 
[15] Elham Amini Baghbadorani , Ali Roohani. The Impact of Strategy-based Instruction on L2 Learners' Persuasive Writing. Procedia - Social and Behavioral Sciences 2014; 98: 235. http://www.sciencedirect.com/science/article/pii/S1877042814025038

[16] Ellis, R. 1994. The study of second language acquisition. Oxford: Oxford University Press.

[17] Graham, Santos and Vanderpank.(2011). Exploring the relationship between listening development and strategy use. Language Teaching Research.vol.15.No.4.435-456.

[18] Gu.Y. (2007). Strategy-based instruction. In T. Yashima\&T. Nabei(Eds.), Proceedings of the International Symposium on English Education in Japan: Exploring New Frontiers(pp.21-28). Osaka:Yubunsha.

[19] Hong Liu. (2011). SBI on undergraduates'English reading teaching practice. Journal of Hexi University(6):108-112.Zhangye, Gansu.

[20] Joan Rubin \& I. Thompson. (1994). How to be a more successful language learner. Boston: Heinle\&Heinle.http://www.tesl-ej.org/ej03/r14.html.

[21] L. Mark Carrier. (2003).COLLEGE STUDENTS' CHOICES OF STUDY STRATEGIES. Perceptual and Motor Skills: Volume 96, Issue, pp. 54-56.

[22] Magnus Wilson. (2003). Discovery Listening-improving Perceptual Processing. ELT Journal, 57(4):335-343.Oxford

[23] McDonough, S. H. (1995). Strategy and skill in learning a foreign language. London:Edward Arnold.

[24] Mendelsohn, S. H. (1994). Learning to listen: A strategy-based approach for the second-language learner. San Diego: Dominie Press.

[25] Morley, J. (2001). Aural comprehension instruction: Principles and practices. In M.Celce-Murcia(Ed.), Teaching English as a second or foreign language(3rd ed):69-85

[26] Nunan, D. Listening in language learning. The Language Teacher, 23(9), 47-51.

Nobuko Osada.(2004).Listening comprehension research: a brief review of the past thirty years.Dialogue(3):53-66.

[27] O'Malley, J.M. \& Chamot, A.U. (1990). Learning Strategies in Second Language Acquisition. Cambridge: Cambridge University Press.

[28] Oxford, R. L. (1990). Language learning strategies: what every teacher should know. Boston: Heinle\& Heinle

[29] Oxford, R. L.(2001). Language learning styles and strategies. In M. Celce-Murcia(Ed.), Teaching English as a second or foreign language(3rd.359-366).Boston:Heinle\&Heinle.

[30] Qingquan Ni.(2014). The Review of Learning Strategies in Recent 40 Years. The Journal of the Foreign Language University of Sichuan Province (6) : 136.

[31] Qiufang Wen, Lifei Wang.(2004). The empirical research about learning strategies in recent 20 years in China. Foreign Language and Literatures(1):39-45. Fuzhou, China.

[32] Rana Yildirim, (2015). Strategy-based English language instruction: the impact on the language proficiency of young gifted learners. Education (2): 97-114. http://dx.doi.org/10.1080/03004279.2012.759606.

[33] Rubin (1987) described, learningstrategies are strategies that contribute to the development of the language systemthat construct and affect learning directly. As Oxford (1990:18-22) 
[34] Thitipat Watthjarukiat, (2012). An Investigation of English Listening Strategies Used by Thai Undergraduate Students in Public Universities in the South. Unpublished M.A dissertation, Prince of Songkla University.Thailand.

[35] Wenden, A.(1991). Learner Strategies for Learner Autonomy. Englewood Cliffs, NJ: Prentice-Hall.

[36] Wen, Q., \& Johnson, R.K. (1997). L2 learner variables and English achievement: A study of tertiary-level English majors in China. Applied Linguistics, 18, 27-48.

[37] Xiaofang Gao. (2004). The impact of SBI on Chinese undergraduates' oral English class. Foreign Language world No.6 2004(General Serial No.104)15-21.Beijing, China

[38] Yunlin Shi. (2008).A Study of English Learning Strategies Employed by Senior Middle School Students in Wuhan City. Unpublished MA dissertation, Hubei University of Technology. Wuhan, China.

[39] Yurong Zhen. (2011). The review of learning strategies research in recent 10 years in China.Foreign Language World(3):82-96.Shanghai, China. 